\title{
Changes in social capital of rice farmers: An antropological study for buginese farmers
}

\author{
Thamrin Pawalluri1 ${ }^{*}$, Darmawan Salman², Imam Mujahidin Fahmid ${ }^{2}$, Hidayat \\ Marmin 3 , Arfenti Amir ${ }^{4}$ Amruddin Ambo Enre ${ }^{5}$
}

1 Sekolah Tinggi Keguruan dan Ilmu Pendidikan (STKIP) Cokroaminoto Pinrang, Indonesia

2 Universitas Hasanuddin, Indonesia

3 Universitas Pepabri Makassar, Indonesia

4 Universitas Megarezky Makassar, Indonesia

5 Universitas Muhammadiyah Makassar, Indonesia.

* Correspondence author: thamrinpawalluri1970@gmail.com

\begin{tabular}{|c|c|}
\hline ARTICLE INFO & ABSTRACT \\
\hline $\begin{array}{l}\text { Keywords: } \\
\text { social change; social } \\
\text { capital; farmers; rice fields; } \\
\text { local wisdom. } \\
\text { How to cite: } \\
\text { Pawalluri, T., Salman, D., } \\
\text { Fahmid, I.M., Marmin, } \\
\text { H., Amir, A., Enre, A.A. } \\
\text { (2021). Changes in social } \\
\text { capital of rice farmers: An } \\
\text { antropological study for } \\
\text { buginese farmers. Etnosia: } \\
\text { Jurnal Etnografi } \\
\text { Indonesia, 6(1), 116 - } 124 . \\
\\
\text { DOI: } \\
\text { 10.31947/etnosia.v6i1.14138 }\end{array}$ & $\begin{array}{l}\text { Local institutions that encourage self-organization to achieve shared- } \\
\text { goals is a characteristic of social capital. In Bugis society, there is a } \\
\text { social capital in farming communities called tudang sipulung, } \\
\text { meaning "sitting together for deciding various matters related to } \\
\text { farming". However, tudang sipulung has been transformed. This } \\
\text { study aims to determine causes, processes, and consequences of social } \\
\text { change in tudang sipulung tradition. The data from this case study } \\
\text { were collected by using in-depth interviews, observations, and } \\
\text { document review. The results show that the cause of change was an } \\
\text { abandonment of traditional rituals in farming because farmers } \\
\text { consider that such rituals delay activities and require more cost, so to } \\
\text { reduce the effectiveness and efficiency. In addition, there is also a shift } \\
\text { in the position of actors, where the schedule of the planting which was } \\
\text { previously determined by indigenous knowledge possessed by } \\
\text { traditional leaders, changed to the role of climatologists and officers } \\
\text { from the government. The process of social change takes long and slow } \\
\text { along with the social dynamics of the rice farming community which } \\
\text { makes tudang sipulung tradition as a place to work together to } \\
\text { achieve shared-goal for farmers. Nevertheless, the process of social } \\
\text { change has consequences for the elimination of kindness to each other } \\
\text { and lack of trust among farmers. }\end{array}$ \\
\hline
\end{tabular}

\section{Introduction}

Social capital is a description of internal engagement that characterize the collective structure and provide cohesiveness and mutual benefits from social dynamics processes that occur in society (Cahyono, 2012). According to Bourdieu social capital consists of 2 (two) dimensions: 1) social networks and connections/relationships and 2) sociability. Bourdieu specifically explains that people must not only have relationships with others, they must further understand how these networks operate and how one can maintain 
and utilize these relationships over time. Particularly, Bourdieu emphasizes that social networks must be constructed and then skillfully maintained in order for the actor to utilize their resources (Saheb, 2013).

Tudangsipulung is a tradition and as a forum for playing social functions and roles is so needed by farmers in Indonesia in an effort to achieve shared-goals. Such in Pinrang district, the role of social capital is an urgent part in the current conditions considering that the farming is majority. The role of tudangsipulung as a tradition is able to give capability to achieve shared-goals. Institutions in the live of communities undeniably formed because they are related to the encouragement of elements of social capital includes trust, social networks and social institutions (Syofian, 2020). The implementation of deliberation that is able to achieve agreement or called massiddi'adaenagau'ewe (only words with actions) in encourages, a. Mappile bine iyewe meloitaneng (selecting seeds to plant); b. Mappatantu wattunnae mapppammula maggalung'e (decide the time to down the fields); c. Mappatantu wattue mappammula mattaneng (decide the time to plant). Realizing the activities of farmers deliberation will certainly provide benefits and vice versa if not implemented will bring various negative consequences (Fahmid, 2013).

The activities of farming community in order to create togetherness among them, performing a tradition before starting the planting, namely tudangsipulung which prioritizes collective work in cultivating fields. Farming communities are given leeway in gaining access to participate in contributing to managing natural resources through the efforts and coordination of various related elements (Soetomo, 2013) so as to create good social dynamics. Efforts to participate in village communities in managing the potential of their territory need to be given the maximum possible space for movement. in order to create harmonization (Fahmid, 2012).

A description of rice farmers activities has been widely studied by previous researchers, for example efforts to strengthen farmers social capital in Boyolali district that focuses social capital is able to provide reinforcement for farming, especially in the context of cooperation for shared-goals (Tri Pranadji, 2000). The role of extension workers in providing assistance to rice farmers as an analysis that the presence of extension workers is very beneficial (Indraningsih, 2011). Another study on the role of farmer groups in providing assistance to rice farmers to obtain farm loan assistance (Fahmid, 2013). Analysis of social capital for rice farmers to further streamline the performance of farming cooperatives in Subang and Karawang so that these rice farmers can improve their economy (Anggita, 2013).

A description of increasing the capacity of social capital and human resources in mentoring rice farmers farming in order to improve the level of the economy (Susanto, 2010). Analysis of the pattern of farming adoption by increasing farming in South Sumatra to improve the economy of farming communities (Junaidi et al, 2010). The supporting factors in farming are analyzed through effective institutional performance through program socialization efforts, a bottom-up participatory approach, and involving the farmer mother (Wahyuni, 2003). 
Efforts to analyze the strengthening of social capital by studying sustainable livelihood strategies for farming communities in Tuban district (Widodo, 2012). A description of the factors that influence farming in Ciamis district found that land factors and farmer participation in training activities had a significant effect on rice production (Isyanto, 2012). Studies on additional capital for rice farmers in Blitar and Ngawi districts as an effort increase farmer production are successful (Hermawan et al, 2013). Analysis of the integrated crop-livestock farming system found that some farmers carry out activities by running a crop-livestock system (Sudjana, 2007).

Understanding the types of previous research results that are related to this research, it can be concluded that the study of the process of changing the tudangsipulung tradition in Data village of Pinrang district is a social phenomenon that has never been studied before. Empirical facts show that the process of implementing tudangsipulung activities underwent a change in social aspects and dimensions. Change in society in principle is a continuous process, meaning that every society will in fact experience changes (Sztompka, 2011) but changes between groups and other groups are not always same and many factors influence it.

This paper aims to explore the impact of social capital of rice farmers in tudangsipulung tradition. This can inform the design of future agricultural extension programs. This is then applied to empirical data and the results discussed. The paper concludes with some remarks and recommendations. An analytical effort in this study focuses on social change which distinguishes it from previous research. It aims to determine the process of sustainable social change in tudangsipulung tradition as well as the consequences of social changes in tudangsipulung tradition for buginese farmers.

\section{Method}

The design of research is a case study with case unit is a village. The location is Pinrang district, South Sulawesi province, Indonesia. The researcher focus on data "tudangsipulung tradition" as social capital, causes of social change, processes of social change, and its consequences. Collecting data through observation and in-depth interviews, and researchers act as research instruments. The data obtained is causes, process and consequences of changes. The entire data collected is verified and then analyzed using interactive, comparative and interpreted analysis techniques (Creswell, 2014) and it intended to write a description of the process of social change in Tudangsipulung traditional. The stages of data collection and analysis follow a cyclical flow are interactive and take place continuously until complete, so that the data becomes saturated. The concept includes data reduction, data display, and conclusion: drawing/verifying (Creswell, 2014).

\section{Causes of social change in tudangsipulung tradition}

The meaning of tudangsipulung tradition is a series of two words in Bugis language that form one compound word. Tudang has a meaning of sitting while sipulung means got together, so literally, tudang sipulung means sitting together (Manyambeang, 1984). The purpose of tudangsipulung tradition is to discuss three main components, namely: (1) to 
uniform the seeds to be planted; (2) to uniform the time of starting down the rice field and 3. to uniform the timing of rice planting (Manyambeang, 1984).

The ceremonial of tudangsipulung traditon begins with the gathering of the farming community at a predetermined place, namely deliberation at the village level followed by Palontaraq (traditional leaders who have expertise in reading natural and climatic signs that are closely related to agricultural problems), Pappananrang (traditional leaders who have the ability to read natural signs related to pests/diseases that attack farmers). However, usually these two fields are carried out by one person, village officials and rice farmers (Buraerah, 2013). These four components carry out the process of tudangsipulung ceremony to talk about various things related to the start of farming. The focus of the discussion on the deliberation activity consisted of 12 steps in the rice field management process.

According to Buraerah (2013) that in accordance with the decision of Nene Mallomo there are twelve steps in the process of working on rice fields, namely: (1) Sapana sange seri (do not do misdeed when first go down the field); (2) Mappalili (precaution from evil); (3) Mappano Bine (selecting seeds); (4) Mannawo (mampo bine) (sowing seeds); (5) Massisi (winkle out seeds); (6) Mappamula Mattaneng (started to plant rice); (7) Mabbuwani Asewe (when the rice begins to fruit); (8) Mappangideng Ase (initial ritual so that the rice content is good); (9) Pappalise Ase' sibawa bacana ko tomappalise ase (ritual for the rice is quality); (10) Mabbura Carila Ase (precaution if rice is affected by pests); (11) Mabbura ko nanrewi ule' Asewe (precaution of pest); (12) Mappamula Mangngala (starting harvesting).

The dynamics of the life of farming community in Data village, Pinrang district are always undergoing a process of social change. A hereditary habit whose implementation is closely related to the agricultural sector which is the main orientation of agricultural development (Fahmid, 2004). According to Sztompka (2011) changes in one aspect will be biased to other aspects. Over the course of time, the tradition that was initiated and pioneered by an astute scholar Addaowang Sidendreng, named Nene Mallomo around the XV century was given the name tudangsipulung (Buraerah, 2013). The process of the presence and development of this tradition in Sawitto region is estimated to be in the sixteenth century. The implementation of Tudangsipulung deliberations is always activated by the kingdom together with the community at the beginning of farming. The deliberation process carried out in Sawitto has many similarities with the implementation in Sidenreng, especially when La Todani became Addatuang Sawitto as well as ruling in Sidenreng (Moenta, 1988).

The results of research indicates that the causes of the process of social change in tudangsipulung tradition are: a. part of the farming communities no longer exercise traditional ritual activities such as; holding offerings with various facilities that must be present and carrying out a procession to the designated seed nursery for mangngampo' (sowing) seeds as the ancestors did with excuses. They do not really understand the meaning and ways of implementation. According to them, the traditional procession only delaying the activities of the farmers. The implementation of traditional procession requires a lot of money. There are some rice farming communities who believe that this act is against religious law. 


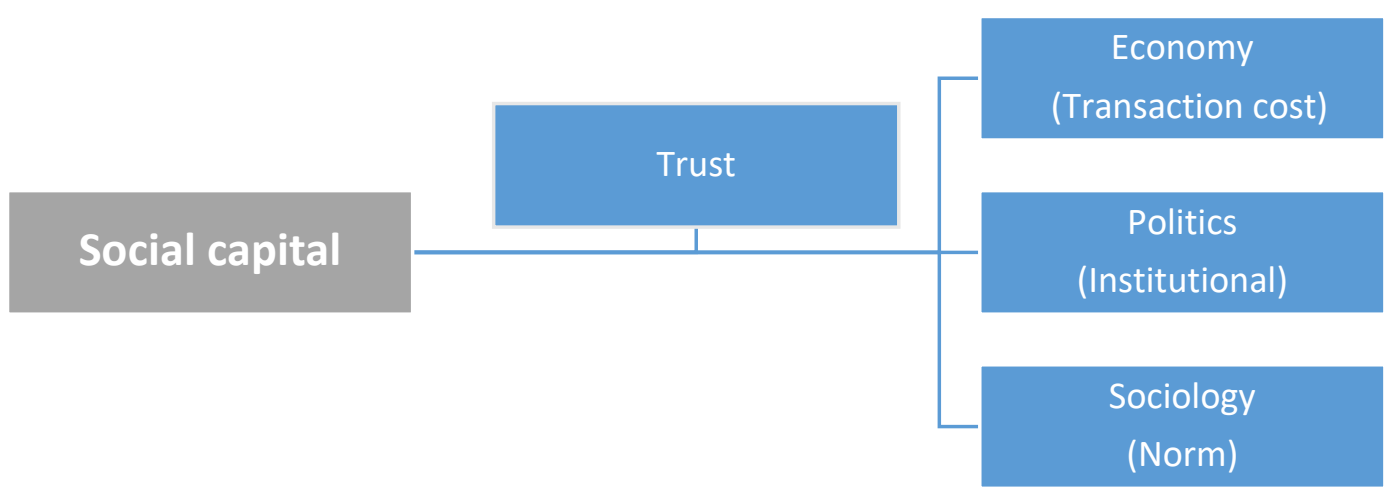

Figure 1. A cheme of social capital operationalization

The development of appropriate agricultural technology such as tractors and the inclusion of a system of planting wages, spray wages and rice maintenance wages. The role of palontaraq and pappananrang actors in the process of tudangsipulung tradition is very important because their vital function is to explore, study and analyze the state of natural astronomy. The results of this research are used as a reference at the time of tudangsipulung deliberation to determine the initial schedule to down the fields. This important role is gradually changing due to the presence of Meteorology and Geophysics Agency and Irrigation actors in helping to analyze the climate and weather before tudangsipulung deliberation is held.

According to La Nalefo (2013) that parabela as social capital in local farmers institutions has changed its function due to the intervention of agricultural extension workers. Sustainability of social change in farming communities occurs in the variety of causes as a trigger for the change in complexity. Changes that emerged in the tudangsipulung tradition led to the addition of actors in deliberation activities as an effort to more accurately assess the results of studies on climate and weather. This certainly reduces the dominance of palontaraq/pappananrang actors and socially contributes to the status of palontaraq actors in the rice farming community in Pinrang district.

Above all, social capital has three dimensions: cognitive, social capital, and two forms of structural social capital (bonding and bridging) van Rijn et al. (2012). Cox (2002) describes beliefs and norms in economic traditions that can develop and provide information that creates positive incentives for cooperation. Elements of social capital significantly influence economic growth through various mechanisms, such as increasing a sense of responsibility towards the public interest, expanding participation in the democratic process, strengthening community harmony, and decreasing levels of violence and crime.

The process of social change that occurs in tudangsipulung tradition lasts a long time as a forum to equalize the desires and achieve common goals for the rice farming community. The efforts of the rice farming community in Pinrang ditrict to always maintain and preserve tudangsipulung tradition are still being encouraged. This 
preservation does not mean that it is free from the influence of the process of change that occurs in the tradition. The continuity of this change has existed since the tudangsipulung tradition was agreed by the rice farming community to be a forum for conducting deliberation at the beginning of descending the fields (Fahmid, 2011).

\section{Consequences of social change in tudangsipulung: development and challenges}

Social changes in tudangsipulung tradition in other aspects and dimensions continue to follow the flow that change becomes the nature of something (Sztompka, 2011). Ontologically it can be said that society is not in a constant state. All social realities are constantly changing according to different degrees of speed, intensity, rhythm and tempo (Sztompka, 2011). Life is movement and change. The process of social change that occurs in the tudangsipulung tradition is a multilinear change in which a number of changes take place, either replacing or adding certain aspects and dimensions.

Social capital affects economic variables like agricultural productivity. In turn, it is affected directly and indirectly by various policies and programs, though not deliberately. In fact, the impact on social capital is rarely considered (Edillon, 2012). This is rather unfortunate though not surprising, considering the dearth of both theoretical and empirical studies on social capital and its impact on economic variables like agricultural productivity.

According to community leaders, during the kingdom period, the farming community (paggalung/pallaoruma) strongly adhered to the togetherness and mutual assistance between them, nakatenni ladde' iyaro iyyaseng (held tightly in question), masse'di (unity), sieteppa'ki (mutual trust) or siasasilassu'reng (brotherly bond), to siappa'decengang (giving each other kindness), makke'ade' (norms or rules), siass'umpungeng lolo (relationship/network towards relatives). The pattern of life of the farming community, which used to be a sense of mutual trust, mutual kindness and high brotherhood, underwent a process of change. The consequences of social change in terms of social relations include giving each other kindness has decreased, mutual trust between actors and structures has decreased, familiarity that is built through social processes begins to fade.

The occurrence of social changes in strengthening the elements of social capital that exist in tudangsipulung tradition such as mutual trust and mutual kindness among farming communities is caused by mappagaji (wages) system for each activity such as wage of tractor to plow the fields, wages to plant rice. The whole activity of the rice farmers in the past was done by helping each other (mutual cooperation) between them. The process of changing from a system of mutual assistance (mutual cooperation) to a wage system has an influence on the existence of giving each other good which was previously nurtured through mutual assistance in turns. The habits of the rice farmers have a strengthening effect on the level of mutual trust that used to be strong in all forms of rice farmer activities. The consequence of the technical change in farming is a decrease in cooperative activities for rice farmers because the plowing of the rice fields has changed 
from animal power/hoeing to all machine. Opportunities to ensure friendship between farmers are reduced.

The farming community is a society that is always characterized and oriented to traditional life, which has the primary goal of meeting the family's needs, not just looking for profit. Homogeneous nature makes the relationship between members more intimate. Hence, this shows that this kind of tradition is a habit that can be interpreted as a culture in farmer groups. Nevertheless, along with the times, the challenges of the large flow of technology are increasingly rapidly changing the order of people's lives, including in the agricultural sector. Farmers are required to be able to compete in providing quality products by utilizing modernized technology. This changed the paradigm that initially, the management process using human power turned into mechanical power and technology. With this change, the tobacco farmer group experienced a perceived obstacle where technological stuttering attacked the farmers. The conflict over the suppression of economic and social values between collectors and farmers was increasingly endless.

There is a socio-technical change in farming that harvest takes place from human/female labor being replaced by machines Yunus (2016). However, as it turns out into practice, institutional solidity, which is reflected in trust, better cooperation, and more effective networks, enables the functions and roles of institutions to run optimally. Theoretically, social capital is always related to social relations or networks. Social capital becomes the concrete capital of individuals and groups that underlies and can utilize social relations to obtain economic benefits and social benefits. So it is necessary to have an attitude of solidarity upheld by tobacco farmers in the face of the new order manifested in several practices in society.

Solidarity is an action that leads to intimacy and cohesiveness, the empowerment of social relations, and as a tool to achieve or realize its goals and ideals. However, familiarity such as social relations is the basis or focus and foremost goal of community life. This condition results in the loss of job opportunities for women when the harvest season arrives. The results of the analysis show that there are two consequences with this change, namely preserving a system of mutual assistance (mutual cooperation) will strengthen emotional relationships that are getting better so as to strengthen reciprocity and mutual trust, strengthen relationships/networks (network) and always maintain good adherence to norms/rules. On the other hand, changing to a wage system will stretch the performance of elements of social capital which will lead to a work system of individualism and thinking about self-interest.

\section{Conclusion}

The ongoing process of social change for farming community in tudangsipulung tradition is caused by the lack of understanding of meaning and ways of implementing traditional procession, the traditional procession requires cost, there are some people who think that the traditional procession is against religious law and the era of agricultural technology such as tractors and harvesting machines and the presence of a wage system when planting rice. The process of changing tudangsipulung tradition lasts a long time due to various social aspects and dimensions, the flow of change through a gradual 
process that is multilinear, namely the process of eliminating some aspects and adding other aspects. This sustainability brings consequences in terms of social and technical relations of farming communities of rice farmers in Pinrang district. There are two consequences for this change, namely surviving with a system of mutual cooperation will strengthen emotional relationships that are getting better so that it strengthens giving each other kindness (reciprocity) and conversely, it is changes to a wage system that will give distance in two elements of social capital which will lead to a more selfish individualism.

Acknowledgement:

Researchers express gratitude to the Faculty of Agriculture, Hasanuddin University, Universitas Pepabri Makassar, Universitas Megarezky Makassar, Universitas Muhammadiyah Makassar for this research collaboration that have supported this research.

Conflict of Interest:

The authors declare that they have no conflict of interest.

\section{References}

Anggita, T. (2013). Dukungan Modal Sosial Dalam Konektivitas Usaha Tani Untuk Mendukung Kinerja Produksi Pertanian Studi Kasus: Kabupaten Karawang dan Subang, Jurnal Perencanaan Wilayah dan Kota, Vol. 24 No. 3: 203-226.

Buraerah. (2013). Analisis Deskriptif Data Riset Kesehatan. Makassar: Masagena Press.

Bourdieu, P., \& Richardson, J. G. (1986). Handbook of Theory and Research for the Sociology of Education. The forms of capital, 241-258.

Cahyono, B., \& Adhiatma, A. (2012). Peran modal sosial dalam peningkatan kesejahteraan masyarakat petani tembakau di Kabupaten Wonosobo. In Conference In Business, Accounting, And Management (CBAM) (Vol. 1, No. 1, pp. 131-144).

Cox E (2002) Australia: Making the Lucky Country. In: Putnam RD (ed) Democracies in Flux: The Evolution of Social Capital in Contemporary Society. Oxford: Oxford University Press, Inc.:395-412.

Edillon, R. G. (2012). Social capital and the decision to adopt new technology among rice farmers in the Philippines. Philippine Journal of Development, 37(1): 1-13.

Fahmid, I. M. (2011). Pembentukan Elite Politik di dalam Etnis Bugis dan Makassar Menuju Hibriditas Budaya Politik. Unpublished doctoral dissertation, Institut Pertanian Bogor, Bogor.

Fahmid, I. M. (2012). Tidal Polarization in Elite Ethnic and Makassar Bugis. Sodality: Jurnal Sosiologi Pedesaan, 6(2).

Fahmid, I. M. (2013). Typology of rural agrarian conflicts. Journal of Economic and Sustainable Development, 4(3), 171-178.

Hermawan, H., \& Andrianyta, H. (2013). Peran tambahan modal terhadap pendapatan usahatani padi di Kabupaten Blitar dan Ngawi, Jawa Timur. Jurnal Pengkajian dan Pengembangan Teknologi Pertanian, 16(2), 132-139.

Isyanto, A. Y. (2012). Faktor-faktor yang Mempengaruhi Inefisiensi Teknik pada Usahatani Padi di Kabupaten Ciamis. Cakrawala Galuh, 1(5), 31-40.

La Nalefo, M.K. Yusoff, M.S.S. Ali, D. Salman, E.B. Demmallino, Meisanti, Muhidin, I.Y. Ismail, M.Kamaluddin, Nurwati, (2013). Towards and Institutional Sustainable Agriculture in Parabela. World Applied Sciences Journal. Vol.26. 
Moenta, A, P. (1988). Sejarah Lahirnya Kabupaten Pinrang, Original Research \& Symposium 28-30 Maret 1988, Dinas Pendidikan dan Kebudayaan Kabupaten Pinrang.

Pranadji, T. (2000). Kumpulan Naskah-Naskah Sejarah Sawitto, Raja-Raja Sawitto, Seksi Kebudayaan, Dinas Pendidikan Nasional Kabupaten Pinrang.

Saheb, S., Slamet, Y., \& Zuber, A. (2013). Peranan Modal Sosial Bagi Petani Miskin Untuk Mempertahankan Kelangsungan Hidup Rumah Tangga Di Pedesaan Ngawi (Studi Kasus Di Desa Randusongo Kecamatan Gerih Kabupaten Ngawi Provinsi Jawa Timur). Jurnal Analisa Sosiologi, 2(1).

Soetomo. (2013), Strategi-Strategi Pembangunan Masyarakat, Pustaka Pelajar. Yogyakarta.

Susanto, D. (2010). Strategi peningkatan kapasitas modal sosial dan kualitas sumberdaya manusia pendamping pengembangan masyarakat. Jurnal Komunikasi Pembangunan, 8(1).

Syofian, S., Sujianto, S., \& Handoko, T. (2020). Modal Sosial Kelembagaan Petani Karet di Kabupaten Kuantan Singingi. Gulawentah: Jurnal Studi Sosial, 5(1), 52-59.

Sztompka, Piotr. (2011). Sosisologi Perubahan Sosial. Fajar Interpratama. Jakarta.

van Rijn F, Bulte E, \& Adekunle A (2012) Social capital and agricultural innovation in Sub-Saharan Africa. Journal of Agricultural Systems, 108:112-122.

Wahyuni, S. (2003). Kinerja Kelompok Tani Dalam Sistem Usaha Tani Padi Dan Metode Pemberdayaannya. Pusat Penelitian dan Pengembangan Sosial Ekonomi Pertanian, Bogor, Jawa Barat.

Widodo, S. (2012). Penguatan Modal Sosial Untuk Pengembangan Nafkah Berkelanjutan Dan Berkeadilan, Program Studi Agribisnis Fakultas Pertanian Universitas Trunojoyo Madura, Jawa Timur.

Yunus, A., Salman, D., Demmallino, E. B., \& Viantika, N. M. (2016). Sociotechnical change and institutional adjustment in paddy rice farming during post green revolution in indonesia. International Journal of Agriculture System, 4(2), 218-227. 